\title{
Maternal and neonatal outcome in rhesus positive women in a tertiary care center
}

\begin{abstract}
Background: Incidence of $\mathrm{Rh}$ negativity in India ranges from 3-5.7\%. Rh negative pregnancy not only poses risk to mother but in the fetus, may lead to dreaded complication like hemolysis and intrauterine fetal demise. However, the advance management and early detection of the condition can prevent the complication.
\end{abstract}

Objective: This study aims to determine the prevalence of Rh negative pregnancy in our population, to study the various maternal and fetal complications.

Materials and methods: A retrospective review from the medical records over a period of 5years, between January 2012 to December 2016 years, conducted in ESIC medical college and hospital, Bangalore. Maternal geographical data and characteristic were collected like, antibody type, antibody titer. Perinatal and neonatal outcome were also collected like the mean gestation age of birth, birth weight, need of NICU care etc.

Results: A total of 528number of women were included in the study. The prevalence of the Rh negative pregnancy was found to be $2.9 \%$. The most common blood group among the Rh negative women was $\mathrm{O}$ negative. 9(1.7\%) of women was found to have a significant antibody titer, whereas Doppler changes indicating fetal anemia was noted in $3(0.5 \%)$. The commonest neonatal complication was jaundice $44(8.33 \%)$. $2(0.3 \%)$ cases had neonatal anemia required a postnatal blood transfusion.

Conclusion: Routine antenatal screening and timely management with intrauterine transfusion are lifesaving method which should be incorporated in daily Obsterstrics practice.

Keywords: Rh negative, alloimmunization, erythrocytes, perinatal, transfusion
Volume 5 Issue 2 - 2017

\author{
Sreelatha S,' Vandana Ambastha, ${ }^{2}$ Chaitra S, ${ }^{3}$ \\ Satish $D,{ }^{2}$ Sandeep ${ }^{2}$ \\ 'Professor, Department of Obstetrics and Gynecology, ESIC \\ Medical College and Hospital, India \\ Junior resident, Department of Obstetrics and Gynecology, \\ ESIC Medical College and Hospital, India \\ ${ }^{3}$ Senior resident, Department of Obstetrics and Gynecology, \\ ESIC Medical College and Hospital, India
}

Correspondence: Sreelatha S, Professor, Department of Obstetrics and Gynecology, ESIC Medical College and Hospital, Bangalore, India, Email dr.sreelatha20II@gmail.com

Received: April 04, 2017 | Published: May 16, 2017

\section{Introduction}

In the year 1940s Landsteiner and Weiner discovered Rh factor within the blood type it derives its name from the monkey Macacus rhesus, of whom $85 \%$ is shared by the human red cell antigen. ${ }^{1,2}$ In the year 1953 Chown described the pathogenesis of $\mathrm{Rh}$ alloimmunization and explained it to be caused by the passage of Rh-positive red blood cells of the fetus, transplacentally during pregnancy, labour or after delivery which to the mother is antigenic. ${ }^{3}$ Basques have the highest incidence of the Rh negative blood group constituting to $34 \%$. In India the incidence varies between $3-5.7 \% .^{4-6}$ In the year 1996, a study conducted by the U.S. Center for Disease Control and Prevention, recorded a total of 21 deaths of children caused by hemolytic disease (erytroblastosis fetalis) and jaundice. Antenatal determination of the maternal blood type limits the adverse effect on the mother and the fetus. Erythoblastosis is a serious condition affecting about 4000 babies. In close to $15 \%$ of the diagnosed cases the babies die prior to birth, whereas the survives suffer from conditions like jaundice, which further leads to the speech disturbances, deaf-muteness, mental retardation and cerebral palsy.,

$\mathrm{Rh}$ antigens is a lipoprotein molecules, which is located on the surface of the erythrocytes. Various types of antigens are identified on the surface of the erythrocytes, of whom the D antigen is the most immunogenic and upto 50 times more often than the $\mathrm{C}$ and $\mathrm{E}$ antigens. ${ }^{2,7,8} \mathrm{Rh}$ system antibodies are almost always immune, which are predominantly of the $\operatorname{IgG}$ class, which due to its size can pass through the umbilical cord and cause hemolytic disease of the newborn (HDN). The antibodies are directed against antigens which are of the paternal origin, which are present in the child's erythrocytes. This occurs when the fetal red blood cell enter the maternal circulation triggering the immue system. ${ }^{7,9}$ There is a high possibility of the erythrocytes to enter the maternal circulation following amniocentesis, spontaneous or induced abortion, cardiocentesis, chorionic villus sampling, ruptured ectopic pregnancy and a blunt trauma to the abdomen. ${ }^{9}$

\section{Material and methods}

Our study was a retrospect study, data was retrived from the electronic medical records of pregnant women who attended the obstetrics and gynecology department in ESIC medical college and hospital Bangalore, between January 2012 to December 2016. Women blood group, $\mathrm{Rh}$ factor and antibody screen done in the routine antenatal checkup was tabulated. The study population included all women with $\mathrm{Rh}$ negative blood group who has routine antenatal checkup and delivered with us. Data was collected regarding maternal age, gravidity, parity, previous miscarriage, previous blood transfusions, type of minor RBC antibodies and their titer, obstetric and medical history, gestational age at critical titer, gestational age at first MCA Doppler and gestational age at which MCA Doppler showed evidence of fetal anemia. Blood group (ABO) and the Rh factor to determine the prevalence of Rh-positive blood group among the study population, indirect coombs test, titers if found positive, coombs test on the cord blood etc. was collected and tabulated. The antibody titer of 1:16 or more was considered as critical titer. Women with titers of antibody more than the critical value were followed up by serial MCA Doppler every 1-2weeks. Patients who showed high MCA Doppler were treated based on the gestation age. Information regarding including the following was also recorded, fetal complications, 
gestational age at delivery, and mode of delivery, birth weight, Apgar score, neonatal blood group, hemoglobin, neonatal complications, postnatal blood transfusion and neonatal death was also gathered.

\section{Results}

A total of 528 pregnant women were included in our study, which extended for 5years (between January 2012 to December 2016). We had a total of 17677 numbers of antenatal cases in this duration. Making the prevalence of the Rh negative women $2.98 \%$. Table 1 shows the various maternal demographic characteristics of $9(1.7 \%)$ alloimmunized pregnant women. the mean age of the women was 31.2 years, predominantly multiparous 398 (75.3\%). Gravidity of these women was between 1 to $7.42(7.9 \%)$ of the women had history of miscarriage in the past. History of blood transfusion was positive in $37(7 \%)$, common indication for which was dietary anemia. $298(56.4 \%)$ were delivered vaginally (spontaneous vaginal delivery [SVD]), while $230(43.5 \%)$ had cesarean section, shown in Table 2 . A total of $9(1.7 \%)$ of cases were diagnosed with significant alloimmunization. These patients were subjected to MCA - PSV Doppler once in every 1-3weeks. 3(0.5\%) had MCA Doppler suggestive of fetal anemia. The perinatal outcomes in tabulated in the table 3, 2(0.3\%) showed evidence of fetal anemia, 9(1.7\%) women had oligohydramnios, $7(1.32 \%)$ polyhydramnios, $26(4.92 \%)$ had intrauterine growth retardation, $4(0.75 \%)$ has intrauterine fetal demise (Table 3). The commonest neonatal complications were jaundice $44(8.33 \%)$

Table I Maternal characteristics

\begin{tabular}{|c|c|c|}
\hline Maternal Characteristics & $\begin{array}{l}\text { Number of Women } \\
(n=582)\end{array}$ & Percentage $(\%)$ \\
\hline \multicolumn{3}{|l|}{ Maternal Age } \\
\hline$<20$ & 146 & 27.6 \\
\hline $20-30$ & 321 & 60.7 \\
\hline$>30$ & 61 & 11.55 \\
\hline \multicolumn{3}{|l|}{ Gravidity } \\
\hline 0 & 130 & 24.6 \\
\hline 1 & 124 & 23.4 \\
\hline 2 & 97 & 18.3 \\
\hline 3 & 77 & 14.5 \\
\hline 4 & 52 & 9.8 \\
\hline 5 & 16 & 3.03 \\
\hline \multicolumn{3}{|l|}{ Gestation age (wks) } \\
\hline$<28$ & 2 & 0.3 \\
\hline $28+1$ to 32 & 98 & 18.5 \\
\hline $32+1$ to 37 & 198 & 37.5 \\
\hline$>37$ & 230 & 43.5 \\
\hline \multicolumn{3}{|l|}{ Number of Mischarges } \\
\hline 0 & 486 & 92.04 \\
\hline 1 & 22 & 4.16 \\
\hline 2 & 9 & 1.7 \\
\hline 3 & 7 & 1.32 \\
\hline 4 & 4 & 0.7 \\
\hline \multicolumn{3}{|c|}{ History of Blood Transfusion } \\
\hline Yes & 37 & 7 \\
\hline No & 491 & 92 \\
\hline
\end{tabular}

\begin{tabular}{|c|c|c|}
\hline Maternal Characteristics & $\begin{array}{l}\text { Number of Women } \\
(\mathrm{n}=\mathbf{5 8 2})\end{array}$ & Percentage $(\%)$ \\
\hline \multicolumn{3}{|c|}{ History of Receiving Anti d Antibody in the Past } \\
\hline Yes & 299 & 56.6 \\
\hline No & 99 & 18.7 \\
\hline $\begin{array}{l}\text { Pregnancy complicated with } \\
\text { Hypertension complicating } \\
\text { pregnancy }\end{array}$ & 37 & 7 \\
\hline Polyhydramnious & 7 & 1.3 \\
\hline Oligohydramnious & 9 & 1.7 \\
\hline PROM & 32 & 6.06 \\
\hline Abruption & 2 & 0.3 \\
\hline PPH & 29 & 5.4 \\
\hline
\end{tabular}

Table 2 Mode of delivery

\begin{tabular}{lll}
\hline $\begin{array}{l}\text { Mode of } \\
\text { delivery }\end{array}$ & Number of women $(\mathbf{n = 5 2 8})$ & Percentage (\%) \\
\hline Vaginal & 298 & 56.4 \\
Spontaneous & 267 & 50.5 \\
Induced & 31 & 5.87 \\
Vacuum & 9 & 1.7 \\
Forceps & 6 & 1.1 \\
Section & 230 & 43.5 \\
Emergency & 132 & 25 \\
Elective & 98 & 18.5 \\
\hline
\end{tabular}

Table 3 Neonatal outcome

\begin{tabular}{lll}
\hline Neonatal Outcome & Number & Percentage \\
\hline IUFD & 4 & 0.75 \\
Hemoglobin at birth $<6$ at birth & 2 & 0.3 \\
Need of NICU & 39 & 7.38 \\
Need of phototherapy & 42 & 7.95 \\
Need of post-natal blood transfusion & 2 & 0.3 \\
\hline
\end{tabular}

\section{Discussion}

$\mathrm{Rh}$ antigens are found on the surface of the red blood cells (RBC) and Rh D antigen is the one which is immunogenic. The red blood cell without the $\mathrm{Rh}$ antigen are found to have a abnormal shape and increased osmotic fragility leading to a shorter life span of the cell leading to hemolysis. Even today with tremondrarous improvement in the medical field in a developing country like India it is still a important reason for hyperbilirubinemia. ${ }^{10-12}$ The incidence in our study was found to be $2.98 \%$ in comparison to the study performed by Mondal et al. ${ }^{13}$ were the incidence was found to be $2.4 \% .{ }^{13}$ Multigravida in our study was 398(75.3\%) and that of the Primigravidas were 130(24.6\%) in comparison to a study performed by Bondagji et al., ${ }^{14}$ where the results were similar. ${ }^{14} \mathrm{O}$ negative was the most common $\mathrm{Rh}$ negative blood group in our study which was similar to what found in a study conducted by Okeke et al. ${ }^{15}$ Previous history of miscarriage was found 
in $42(7.9 \%)$ which was significantly lower than the once found in Bondagji's study $44.8 \%$ and Pahuja et al. ${ }^{16}$ History of blood transfusion was noted in 37(7\%) in our study in comparison to only $4.5 \%$ stated in Bondage et al., ${ }^{14}$ whereas the indication for transfusion was found to be the same in both the study, anemia. We noted alloimmunisation rate in the D antigen-negative group was $9(1.7 \%)$ which was much lower than in a study conducted by Lurie et al., ${ }^{17}(0.9 \%)$ but much higher in a study conducted by Al-Ibrahim et al., ${ }^{18}$ (7.1\%). This can be attributed to the lack of implementation of standardised and universal anti-D immunoprophylaxis in India.

$298(56.4 \%)$ of the women delivered vaginally and $230(43.5 \%)$ by section the common indication for which was fetal distress. In comparison to a study conducted by Gorle et al., the results obtained were similar $37(7 \%)$ cases developed preeclampsia, $26(4.9 \%)$ cases developed fetal growth restriction, $2(0.3 \%)$ cases associated with abruption. ${ }^{19}$ We found that $9(1.70 \%)$ of the women to have a positive indirect Coombs test. They were further investigated and followed with regular Doppler of the MCV. 3(0.5\%) of the women had features suggestive of fetal anemia and 2 of these neonates required postnatal transfusion. The neonatal outcome was found to be similar to those found to the study conducted by Gorle et al., 524(99.2\%) were live born babies out of whom 3 had a early neonatal deaths. The clinical presentation of the fetus depended on the severity of isoimmunisation, i.e. hydrops fetalis, icterus gravis neonatorum or congenital anemia of the newborn. The apgar score of the neonatal were above 8 in $499(94.5 \%)$ of the total children born. 39(7.38\%) of the babies needed NICU admission. $2(0.3 \%)$ babies needed postnatal blood trsfusion. $42(7.95 \%)$ of the babies had early onset of jaundice as they were Rhpositive babies, 4 of whom had a bilirubin levels more than $18 \mathrm{mg} / \mathrm{dL}$.

\section{Conclusions}

In south India the prevalence of Rh negative pregnancy is lower $<5 \%$, Rh isoimmunisation still remains the determining factor for the perinatal morbidity. Hence routine antenatal screening and timely management with intrauterine transfusion are lifesaving method which should be incorporated in daily Obsterstrics practice.

\section{Acknowledgements}

None.

\section{Conflict of interest}

The author declares no conflict of interest.

\section{References}

1. Joseph KS, Kramer MS. The decline in Rh hemolytic disease: Should Rh prophylaxis get all the credit. Am J Public Health. 1998;88(2):209-215.

2. Roderic PH. Hemolytic Disease of the Newborn (Erythroblastosis Fetalis). In: Abraham M, et al. editors. Appleton \& Lange, USA: Rudolph's Pedriatic; 1996
3. https://www.healthatoz.com/healthatoz/Atoz/ency/erythroblastosis fetalis_pr.jsp

4. Friedman EA. History. In: Charles AG, et al, editors. Rh Isoimmunization and Erythroblastosis Fetalis. USA: Appleton- Century-Crofts; 1969. p. $12-27$.

5. Walvekar V, Anjaria PH. Historical aspects of rhesus isoimmunization. In: Shah D, et al. editors. The Rhesus Factor, Current Concepts. 1st ed. Jaypee Brothers, India: FOGSI Publication; 2004. p. 1-6.

6. De Gruchy GC. Formation of blood cells; bone marrow biopsy. In: Firkin F, et al. editors. De Gruchy's Clinical Haematology in Medical Practice. 5th ed. USA: Oxford University Press; 1990. p. 1-16.

7. Wagle S. Hemolytic Disease of Newborn. USA: 2006.

8. Grgičević D, Vuk T. Imunohematologija i transfuzijska medicina. Medicinska naklada, Zagreb; 2000. p. 65-68.

9. Rasic S, Haracic M. Praktikum iz imunologije. Univerzitetska knjiga, Medicinski fakultet Univerziteta u Sarajevu, Sarajevo; 2006. p. 53-59.

10. Agarwal S, Najam R, Chowdhary HH. Prevalence of Rhesus Negative Pregnant Population at a Tertiary Care Hospital. Int J Sci Stud. 2015. p. 67-69.

11. Armitage S, Warwick R, Fehily D, et al. Cord blood banking in London: the first 1000 collections. Bone Marrow Transplant. 1999;24(2):139-145.

12. Egesie UG, Egesie OJ, Usar I, et al. Distribution of ABO, Rhe- sus blood and haemoglobin electrophoresis among the undergrad- uate students of Niger Delta state university, Nigeria. Niger J Physiol Sci. 2008;23(12):5-8.

13. Mondal B, Maiti S, Biswas BK, et al. Prevalence of hemoglobinopathy, $\mathrm{ABO}$ and rhesus blood groups in rural areas of West Bengal, India. $J$ Res Med Sci. 2012;17(8):772-776.

14. Bondagji NS. Rhesus alloimmunization in pregnancy. A tertiary care center experience in the Western region of Saudi Arabia. Saudi Med J. 2011;32(10):1039-1045.

15. Okeke TC, Ocheni S, Nwagha UI, et al. The prevalence of rhesus negativity among pregnant women in Enugu, southeast Nigeria. Niger $J$ Clin Pract . 2012;15(4):400-402.

16. Pahuja S, Gupta SK, Pujani M, et al. The prevalence of irregular erythrocyte antibodies among antenatal women in Delhi. Blood Transfus. 2011;9(4):388-393.

17. Lurie S, Eliezer E, Piper I, et al. Is antibody screening in $\mathrm{Rh}(\mathrm{D})$ positive pregnant women necessary? J Mater Fetal Neo-natal Med. 2003;14(6):404-406.

18. Al-Ibrahim NA, Al Saeed AH. Red blood cell alloimmunisation among Saudi pregnant women in the central province of Saudi Arabia. Kuwait Med J. 2008;40:116-123.

19. Devi GR, Patnaik US, Usha P. Prevalence of Rh negative pregnancy in antenatal women with evaluation of maternal and foetal outcome. $J$ Evid Based Med Healthc. 2016;3(98):5400-5403. 